\title{
THE IMPORTANCE OF GRAZING IN THE PRODUCTION OF HEALTHY FOOD
}

\author{
Timea Kiss \\ John von Neumann University, Faculty of Horticulture and Rural Development, Hungary \\ https://doi.org/10.47833/2020.1.AGR.008
}

\section{Keywords: \\ grazing \\ livestock \\ healthy food}

\begin{tabular}{lr}
\multicolumn{3}{l}{ Article history: } \\
Received & 20 Nov 2019 \\
Revised & 10 Dec 2019 \\
Accepted & 15 Dec 2019 \\
\hline
\end{tabular}

\begin{abstract}
Functional quality of food means dynamic quality, which is the biological value of food use and nutrition. Its importance is in disease prevention, health preservation and market gain.[3]
\end{abstract}

\section{Introduction}

The Plains have large meadows with mosaic-like appearance. In Hungary, most of the protected areas of national importance are made up of different types of grasslands, so grasslands are important not only for their grassland management but also for the preservation of natural vegetation. Proper management of nature conservation is extremely important, as it is not only their economic exploitation but also the preservation of their diversity. Extensive animal husbandry has accompanied our history, characterizing Hungarians from before the conquest of Hungary. An integral part of ancient peasant farming was grazing livestock. Extensive uses play a key role in preserving the natural values of habitats [6]. Grazing is necessary to maintain the rich habitats of the species [2]. Nutrition has many implications for the quality and, consequently, nutritional value of milk and dairy products. Nutrition affects the composition, flavor, color of the milk, the fatty acid composition, the consistency, the color of the butter and the quality of the hard cheeses [4].

\section{Method}

The sampling areas are located in the areas of Bugac and Tatárszentgyörgy, southwest of the settlements. The Bugac area is a dry lawn area, while the Tatárszentgyörgy area is a wet area. The grazing pressure uniformly 0,4 livestock unit/ha.

Bugac surveys were conducted in June 1997, 2005 and 2017. Records of Tatárszentgyörgy in June 2007, 2008, 2009 and 2010. For recording, Braun-Blanquet[1] method was followed, using $2 \times$ $2 \mathrm{~m}$ squares. The species names follow the nomenclature of Simon [5].To monitor grazing pressure, lawn use intensity and changes in vegetation, the vegetation was subdivided into three zones and zones away from the stable: Zone A: $0-50 \mathrm{~m}$, with maximum disturbance and trampling. Zone B: There is moderate interference between $50 \mathrm{~m}$ and $150 \mathrm{~m}$. Zone C: Disturbance beyond $150 \mathrm{~m}$ is negligible.

\section{Results}

According to the distribution of species by area and zone of Bugac and Tatárszentgyörgy, by type of treatment, three of the species included in Zone ' $A$ ' recordings were weeds that occurred only here. Ten of the species occurring independently of zones and test sites were weeds. The other species (47\%) are interference tolerant. 
Among the species occurring in both sample areas, species of natural grasslands are significantly present. Among the common species, the components of the natural grasslands show higher cover values in the Tatárszentgyörgy sample area. Species numbers of the Bugac and Tatárszentgyörgy areas (Table 1-2). The highest total occurrence of species was

*Corresponding author. Tel.: +36 76517655

E-mail address: kiss.timea@kvk.uni-neumann.hu

in the Bugac ' $\mathrm{B}$ ' zone, but the Bugac ' $\mathrm{C}$ ' area also had a higher number of species compared to the Tatárszentgyörgy ' $\mathrm{C}$ ' area.

Table 1: Total species stocks of the Bugac coenological surveys in the years under study, annual numbers of species $B$ and $C$

\begin{tabular}{|l|l|}
\hline \multicolumn{2}{|c|}{$1997-2017$} \\
\hline Bugac A & 33 \\
\hline Bugac B & 2 \\
\hline Bugac C & 48 \\
\hline
\end{tabular}

\begin{tabular}{|l|l|l|l|}
\hline & \multicolumn{1}{|c|}{1995} & \multicolumn{1}{|c|}{2007} & \multicolumn{1}{c|}{2017} \\
\hline Bugac B & 38 & 36 & 28 \\
\hline Bugac C & 37 & 41 & 39 \\
\hline
\end{tabular}

Table 2: Total species stocks of the Tatárszentgyörgy coenological surveys in the years under study, species numbers of areas " $B$ " and " $C$ " per year

\begin{tabular}{|l|l|}
\hline \multicolumn{2}{|c|}{$2007-2010$} \\
\hline Tatárszentgyörgy A & 23 \\
\hline Tatárszentgyörgy B & 39 \\
\hline Tatárszentgyörgy C & 38 \\
\hline
\end{tabular}

\begin{tabular}{|l|l|l|l|l|}
\hline & \multicolumn{1}{|c|}{2007} & \multicolumn{2}{c|}{2008} & \multicolumn{2}{c|}{2009} & \multicolumn{2}{c|}{2010} \\
\hline Tatárszentgyörgy B & 28 & 32 & 30 & 30 \\
\hline Tatárszentgyörgy C & 28 & 27 & 32 & 38 \\
\hline
\end{tabular}

\section{Discussion}

The zone near the pen $(A)$ is predominantly weed species, which is the result of severe overgrazing and significant trampling, similar to Middleton [2]. Commonly occurring species in coenological surveys are weeds or disturbances. They are significant in Zone A. The more distant zones "B" and "C" are characterized by the natural vegetation of the dry grassland of Bugac, the sandy pasture and the wetland of Tatárszentgyörgy. In addition to the commonly occurring species in these zones, the proportion of weeds and disturbed species is low. Grazing has slightly altered the species composition of the areas, but in a positive direction. However, grazing has a positive effect not only on the pasture but also on the final product to be used. Among its positive effects, among other things, is the increased vitamin D content of milk when animals are grazing. In contrast, certain weeds can cause unpleasant taste.

In milk and meat-producing herds, where it is based on pasture, the way it is done has a major impact not only on production but also on quality (guarantee and functional). 


\section{Acknowledgment}

Thank you for the support of the research carried out in the framework of the EFOP3.6.2-16-2017-00012 „Developing a functional, healthy and safe food product chain model from field to table in a thematic research network". The project is funded by the Hungarian State and the European Union, co-financed by the European Social Fund, and is part of the Széchenyi 2020 program.

\section{References}

[1] Braun-Blanquet, J. (1964): Pflanzensoziologie 3. Aufl. Wien, Springer-Verlag.

[2] Middleton, Beth A. (2013): Rediscovering traditional vegetation management in preserves: Trading experiences between cultures and continents. Biological Conservation 158:271-279.

[3] Póti P., Pajor F., Láczó E. (2007): Sustainable grazing in small ruminants. Cereal Research Communication. 35.2. 945-948.

[4] Schmidt J. Zsédely E. (2011): Kérődzőállatoktakarmányozása. Nyugat-MagyarországiEgyetem

[5] Simon T. (2000): A magyarországiedényesflórahatározója. Tankönyvkiadó, Budapest.

[6] Sutcliffe, L. M. E. et al. (2015): Harnessing the biodiversity value of Central and Eastern European farmland. Diversity and Distribution 21:722-773. 